\title{
Akinetes of the Cyanobacterium Nostoc PCC 7524: Macromolecular Composition, Structure and Control of Differentiation
}

\author{
By JOAN M. SUTHERLAND, MICHAEL HERDMAN* \\ AND WILLIAM D. P. STEWART \\ Department of Biological Sciences, The University, Dundee DD1 $4 H N$
}

(Received 22 March 1979)

\begin{abstract}
Synchronized akinete differentiation occurred following the transition from exponential to non-exponential (linear) growth, the major trigger being energy limitation. Young akinetes first accumulated cyanophycin, then developed a multilayered extracellular envelope and a thickened wall. The dry weight, chlorophyll $a$, glycogen and carbon contents of mature akinetes were greater than those of vegetative cells, while their contents of DNA, RNA, protein, phycocyanin and nitrogen were similar to those of vegetative cells. Akinetes were resistant to desiccation and low temperatures, but not to temperatures above the maximum for vegetative cell growth.

In $\mathrm{N}_{2}$-grown cultures heterocyst differentiation ceased at the end of exponential growth, while cell division continued, and akinetes first appeared in a regular pattern at a fixed distance ( 9 cells) from the nearest heterocyst. Exogenous $\mathrm{NH}_{4}{ }^{+}$inhibited the differentiation of heterocysts and, in their absence, akinetes developed in irregular positions. The regular spatial pattern imposed on akinete differentiation by heterocysts was, like the heterocyst spatial pattern itself, independent of $\mathrm{N}_{2}$ fixation. Similar changes in both patterns induced by 7-azatryptophan suggested that they share a common mechanism of control.
\end{abstract}

\section{INTRODUCTION}

Various cyanobacteria differentiate akinetes (spores) which serve as perennating structures (see Nichols \& Carr, 1978). The pattern of differentiation varies in different organisms. In Cylindrospermum licheniforme (Fischer \& Wolk, 1976), Anabaena cylindrica (Wolk, 1965) and other akinete-producing Anabaena strains (Rippka et al., 1979), akinetes differentiate from cells immediately adjacent to heterocysts. In the Anabaena strains, chains of akinetes may be subsequently produced in which the youngest are furthest away from the heterocysts. In Nostoc strains (Bornet \& Flahaut, 1888; Rippka et al., 1979) and in Anabaena doliolum (Tyagi, 1974) (which would be classified as a Nostoc strain by the criteria of Rippka et al., 1979), akinetes first differentiate remote from heterocysts and young akinetes subsequently develop sequentially on either side of the first. Heterocysts may be involved in controlling akinete differentiation from vegetative cells (Fritsch, 1904, 1951; Wolk, 1965) and in $A$. cylindrica heterocysts appear to be a necessary prerequisite for akinete differentiation (Wolk, 1966).

Environmental factors reported to induce akinete differentiation in cyanobacteria include low temperature, desiccation, added glutamate, $\mathrm{NaCl}$, high concentrations of sulphate or nitrate, and the absence of combined nitrogen (see Wolk, 1965, for a review of the early literature). None of these conditions were effective in promoting akinete differentiation in

* Present address: Laboratoire de Photosynthèse, Centre National de la Recherche Scientifique, 91190 Gif-sur-Yvette, France. 
$A$. cylindrica but acetate sometimes stimulated the process and calcium glucuronate increased akinete formation significantly (Wolk, 1965); glucose stimulated akinete differentiation in $A$. doliolum (Tyagi, 1974). Akinete-containing cultures of $C$. licheniforme produced an extracellular compound which promoted akinete differentiation when added to young cultures (Fischer \& Wolk, 1976).

Akinetes of $A$. cylindrica differentiated during the late-exponential phase of growth (Fay, 1969b; Simon, 1977a). Simon (1977a) suggested that limitation of inorganic nutrients was not responsible since neither culture density nor akinete formation varied on increasing their concentration. In the same organism, however, phosphate starvation induced, and phosphate inhibited, akinete differentiation although the repressive effect was overcome in old cultures, suggesting that phosphate concentration was not the only important factor (Wolk, 1965). Akinete differentiation in A. cylindrica was unaffected by nitrate in 'standard sporulation medium' (Wolk, 1965) although nitrate, nitrite and ammonium reduced the akinete frequency in $A$. doliolum (Singh \& Srivastava, 1968) and high concentrations of nitrate stimulated differentiation in several Anabaena spp. (Canabaeus, 1929).

Surprisingly, the importance of light or energy limitation in akinete differentiation has apparently not been examined in pure culture, although in the natural environment differentiation occurred under conditions of light limitation within dense surface blooms (Rother \& Fay, 1977). Here we describe the time course and spatial pattern of synchronized akinete differentiation in axenic laboratory cultures of Nostoc PCC 7524, its induction by light or energy limitation, and the structure, macromolecular composition and properties of the mature akinetes.

\section{METHODS}

Organism. The organism studied, Nostoc PCC 7524, was obtained from the Pasteur Culture Collection, Paris, France (Rippka et al., 1979); it is also deposited in the American Type Culture Collection (ATCC 29411).

Culture media and conditions. Stock cultures were maintained in medium BG-11 $($ Rippka et al., 1979) under photoautotrophic growth conditions at $34{ }^{\circ} \mathrm{C}$. Experimental cultures were grown in BG-11, modified by the addition of $\mathrm{NaHCO}_{3}\left(1.6 \mathrm{~g} \mathrm{l}^{-1}\right)$, and sometimes $\mathrm{NaNO}_{3}\left(1.5 \mathrm{~g} \mathrm{l}^{-1}\right),\left(\mathrm{NH}_{4}\right)_{2} \mathrm{SO}_{4}\left(0.7 \mathrm{~g} \mathrm{l}^{-1}\right)$ or glutamine ( $5 \mathrm{mM}$ ), in 11 Quickfit culture vessels fitted with multi-socket lids containing a gas inlet, gas outlet and sampling port. The temperature was $34 \pm 0.5^{\circ} \mathrm{C}$ and the light intensity at the surface of the culture vessel was $8000 \mathrm{~lx}$ (Osram warm white) unless otherwise stated. Cultures were normally gassed with air $/ \mathrm{CO}_{2}(95: 5, \mathrm{v} / \mathrm{v})$, although $\mathrm{Ar} / \mathrm{CO}_{2}(95: 5, \mathrm{v} / \mathrm{v}), \mathrm{O}_{2} / \mathrm{N}_{2}(21: 79, \mathrm{v} / \mathrm{v})$ or air were occasionally used (see Results); with the latter two gas phases, $\mathrm{NaHCO}_{3}$ was omitted from the medium. The cultures were always stirred to maintain homogeneous suspensions. All compounds added to the basal medium were filter-sterilized before use. Growth in liquid culture was determined by measuring the $A_{650 \mathrm{~nm}}^{1 \mathrm{~cm}}$ with a Pye Unicam SP1800 spectrophotometer.

Purification of akinetes. Stationary phase cultures were placed at 0 to $4{ }^{\circ} \mathrm{C}$ for $7 \mathrm{~d}$. During this period the majority of the remaining vegetative cells lysed and their proportion was reduced from $40 \%$ to less than $10 \%$. Akinetes were collected after differential centrifugation.

Protein determinations. The Lowry method was used with bovine serum albumin as standard.

Pigment analyses. Chlorophyll $a$ was extracted twice from pelleted samples in $2 \mathrm{ml} 90 \%(\mathrm{v} / \mathrm{v})$ methanol for $15 \mathrm{~min}$ and its concentration was calculated from the $A_{665}$ of the pooled extracts according to Marker (1972). Phycocyanin was estimated by a modification of the method of Bennett \& Bogorad (1973). Samples were centrifuged, resuspended in saline buffer $(0.15 \mathrm{M}-\mathrm{NaCl}$ in $0.01 \mathrm{M}$-sodium phosphate, $\mathrm{pH} 7.0)$ and disrupted by passage through a French pressure cell at $110 \mathrm{MPa}$. The suspension was centrifuged at $27000 \mathrm{~g}$ for $15 \mathrm{~min}$ and the pellet was used for cyanophycin estimation (see below). The supernatant was centrifuged at $125000 \mathrm{~g}$ for $1 \mathrm{~h}$ and the phycocyanin content was estimated from the $A_{615}$ and $A_{652}$ according to Bennett \& Bogorad (1973).

Glycogen. Analysis was based on the methods of Lloyd \& Whelan (1969), Marshall \& Whelan (1970) and Coulter \& Aronson (1977). Cells were disrupted as for phycocyanin determination, and samples $(0.5 \mathrm{ml})$ were incubated with $0.5 \mathrm{ml}$ amyloglucosidase $\left(1 \mathrm{mg} \mathrm{ml}^{-1}\right.$ in $0.2 \mathrm{M}$-sodium acetate buffer, pH 5.0$)$ at $34^{\circ} \mathrm{C}$ for $2 \mathrm{~h}$. Glucose oxidase reagent (Lloyd \& Whelan, 1969) ( $2 \mathrm{ml}$ ) was added and incubation was continued for $30 \mathrm{~min}$. The $A_{525}$ was measured immediately after the addition of $5 \mathrm{M}-\mathrm{HCl}(4 \mathrm{ml})$. Values from controls (amyloglucosidase replaced with water) were subtracted, and rabbit liver glycogen type III was used as standard. 
Cyanophycin estimation. Cyanophycin was extracted from the pellet obtained by centrifuging disrupted cells at $27000 \mathrm{~g}$ for $15 \mathrm{~min}$ (see Pigment analyses, above) and measured according to Simon (1973).

Carbon and nitrogen contents. A Hewlett Packard 185 CHN analyser was employed, and dry weights were determined on the same samples.

Estimation of DNA and RNA. These were measured by the diphenylamine and orcinol methods, respectively (see Mann \& Carr, 1974).

Nitrogenase activity. The acetylene reduction method of Stewart et al. (1967) was employed.

Photofixation of $\mathrm{CO}_{2}$. Duplicate samples taken from $5 \mathrm{ml}$ of culture were centrifuged, washed and resuspended in $5 \mathrm{ml}$ phosphate buffer $(0.03 \mathrm{M}, \mathrm{pH} 7.5) . \mathrm{NaH}^{14} \mathrm{CO}_{3}\left(2.5 \mu \mathrm{Ci}, 0.4 \mu \mathrm{Ci} \mu \mathrm{mol}^{-1}\right)$ was added and the samples were incubated in the light for $15 \mathrm{~min}$. The reaction was stopped by the addition of $0.1 \mathrm{ml}$ formic acid. The samples were counted in a Nuclear Chicago gas flow counter and corrected for dark assimilation.

Heterocyst and akinete frequencies. At least 1000 cells were counted by light microscopy, and the frequencies of differentiated cells were expressed as a percentage of the total cell population. Mean interheterocyst or interakinete intervals were determined by scoring the number of vegetative cells occurring between at least 100 heterocysts or akinete sites. The positions of newly differentiating heterocysts or akinetes were scored in at least 100 existing interheterocyst intervals and expressed as the distance (percentage of total interval length) from the centre of the interval. Cell counts were performed on suitably diluted samples in a Neubauer counting chamber.

Electron microscopy. Unless otherwise stated the samples were fixed overnight in $3 \%(\mathrm{v} / \mathrm{v})$ glutaraldehyde in $0.1 \mathrm{M}$-cacodylate buffer ( $\mathrm{pH} 7.4)$, post-fixed in $1 \%(\mathrm{w} / \mathrm{v})$ osmium tetroxide in the same buffer, dehydrated in a graded ethanol series and embedded in Spurr's resin. Sections were stained with uranyl acetate $(2 \%$, w/v) and lead citrate. The material was examined using an AEI model EM801 electron microscope.

Chemicals. All chemicals were of the purest grade commercially available. Rifampicin [3-(4-methylpiperazinyliminomethyl)-rifamycin SV], 2-phenylethanol, Dt-7-azatryptophan, amyloglucosidase, glycogen and $o$-dianisidine dihydrochloride were obtained from Sigma, and glucose oxidase and horseradish peroxidase from Boehringer. 3-(3,4-Dichlorophenyl)- $N, N^{\prime}$-dimethylurea (DCMU; from E. I. DuPont) was recrystallized twice before use. All other compounds were obtained from BDH.

\section{RESULTS}

Time course of akinete differentiation. Nostoc 7524 grown on $\mathrm{N}_{2}$ showed a short (approximately $30 \mathrm{~h}$ ) period of exponential growth (doubling time $8.5 \mathrm{~h}$ ), followed by a $100 \mathrm{~h}$ period of non-exponential growth (Fig. 1).

The heterocyst frequency was constant at approximately $9 \%$ during exponential growth, but as growth slowed down during the post-exponential phase, their differentiation ceased. The heterocyst frequency then decreased to $4.5 \%$, and the mean interheterocyst interval increased from 11 to 23 cells (Fig. 1) as vegetative cell numbers doubled in the period from 30 to $70 \mathrm{~h}$.

The initiation of akinete differentiation, recognized by the intracellular accumulation of cyanophycin granules in particular vegetative cells, was first noted in the middle of the non-exponential phase of growth at $70 \mathrm{~h}$ (Fig. 1) and numbers then increased steadily to approximately $60 \%$ of the total cell population when growth ceased at $130 \mathrm{~h}$. The onset of akinete differentiation was well synchronized, occurring simultaneously in $77 \%$ of the interheterocyst intervals.

Changes in macromolecular composition of the culture during akinete differentiation. Chlorophyll $a$, total protein, phycocyanin (Fig. 1), dry weight, and total nitrogen and carbon contents of the culture (Fig. 2) increased with culture density until the onset of akinete differentiation. Further increases in all parameters measured, except dry weight and total carbon, virtually ceased during the phase of akinete maturation (70 to $200 \mathrm{~h}$ ).

Cyanophycin granules were first observed by light microscopy at 60 to $70 \mathrm{~h}$, although quantitative estimations showed that accumulation commenced at $40 \mathrm{~h}$ when the culture was entering the non-exponential growth phase (Fig. 2). Cyanophycin accumulation continued at a rapid rate for a further $30 \mathrm{~h}$ and then at a decreasing rate for $100 \mathrm{~h}$ during akinete maturation.

Changes in photosynthetic ${ }^{14} \mathrm{CO}_{2}$ fixation and acetylene reduction during akinete 


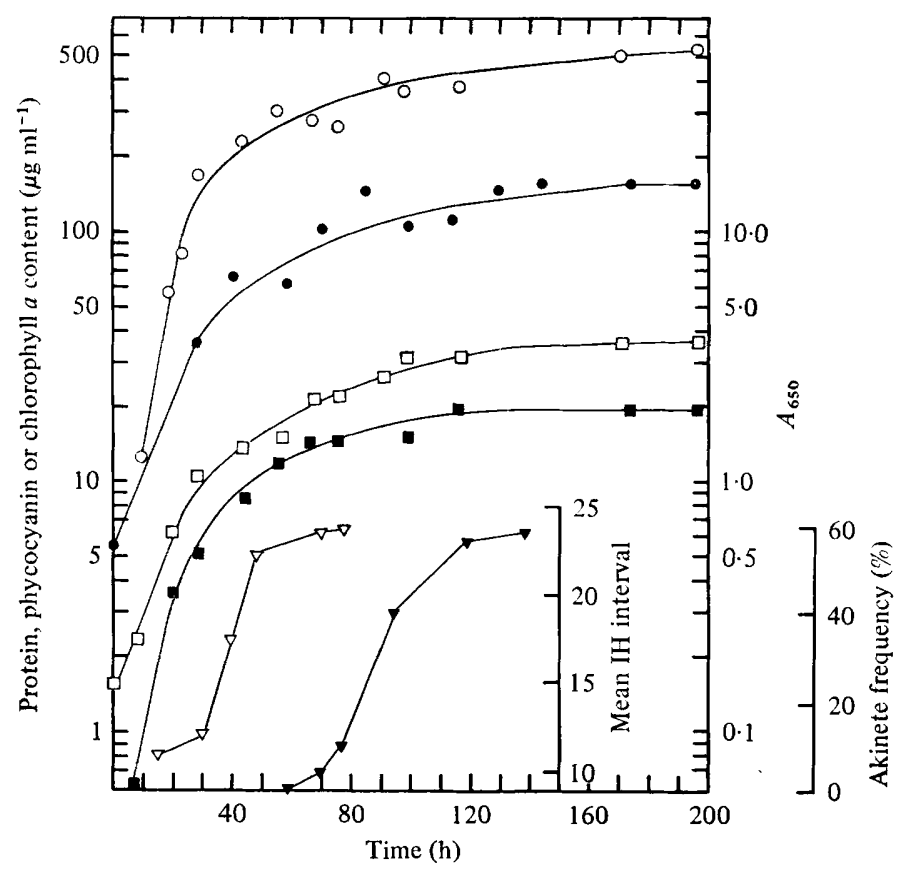

Fig. 1. Total protein (O), phycocyanin (๑), chlorophyll $a(\square)$ and $A_{650}(\square)$ of a culture grown with $\mathrm{N}_{2}$ as sole nitrogen source at $8000 \mathrm{~lx}$. Mean interheterocyst $(\mathrm{IH})$ intervals $(\nabla)$ and akinete frequencies $(\nabla)$ are drawn on linear scales.

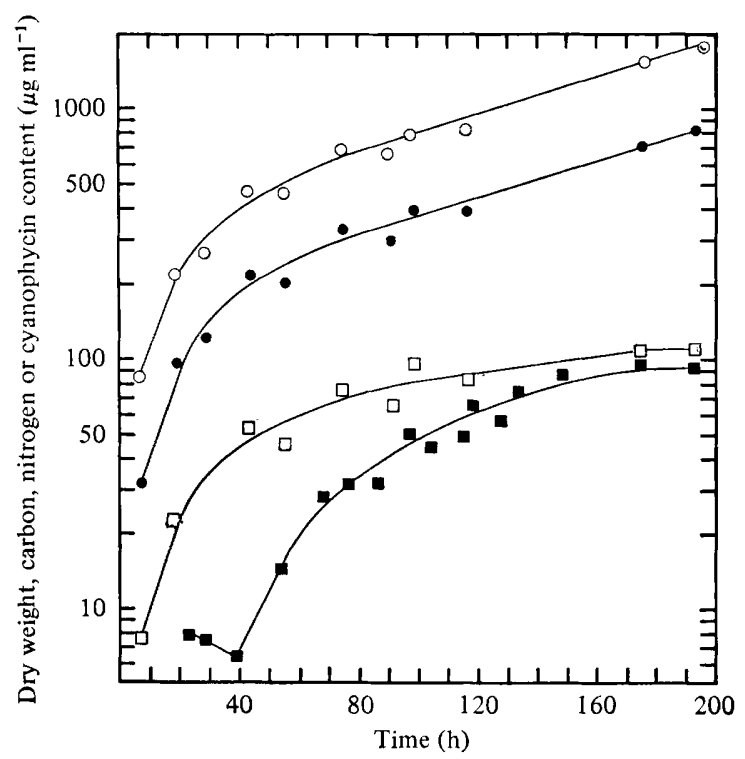

Fig. 2. Culture dry weight $(O)$, total carbon $(\bullet)$ and nitrogen $(\square)$ contents and accumulation of cyanophycin granule polypeptide $(\square)$ during growth with $\mathrm{N}_{2}$ as sole nitrogen source at $8000 \mathrm{~lx}$. Akinetes were first observed microscopically at $70 \mathrm{~h}$. 


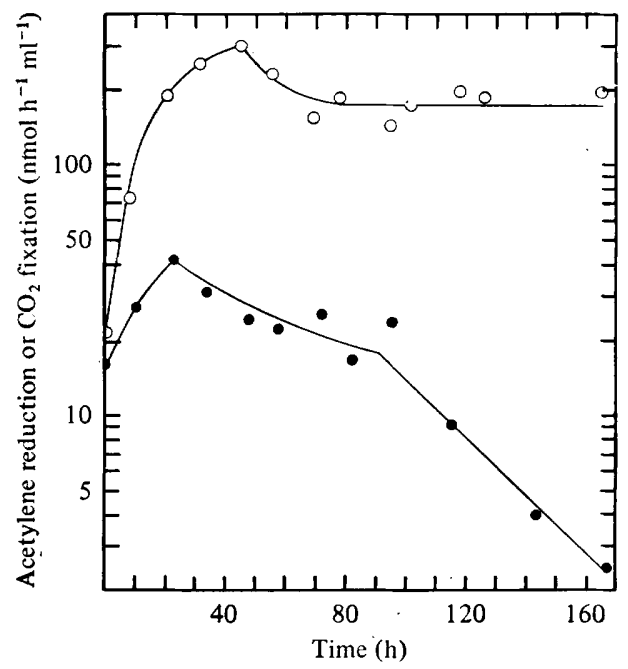

Fig. 3. Rates of $\mathrm{CO}_{2}$ fixation $(O)$ and acetylene reduction (O) during growth with $\mathrm{N}_{2}$ as sole nitrogen source at $8000 \mathrm{~lx}$. Akinetes were first observed microscopically at $70 \mathrm{~h}$.

differentiation. Rates of photosynthetic $\mathrm{CO}_{2}$ fixation were highest (up to $300 \mathrm{nmol} \mathrm{C}$ fixed $\mathrm{h}^{-1} \mathrm{ml}^{-1}$ ) during exponential growth but then decreased (Fig. 3), becoming constant at a rate $\left(180 \mathrm{nmol} \mathrm{h}^{-1} \mathrm{ml}^{-1}\right)$ similar to the rate of increase in total cellular carbon $(210 \mathrm{nmol}$ $\mathrm{h}^{-1} \mathrm{ml}^{-1}$ ) during akinete differentiation and maturation. The rate of acetylene reduction reached a maximum $\left(40 \mathrm{nmol} \mathrm{C}_{2} \mathrm{H}_{4} \mathrm{~h}^{-1} \mathrm{ml}^{-1}\right)$ after $20 \mathrm{~h}$ and thereafter slowly decreased during non-exponential growth and akinete differentiation, becoming negligible as akinete maturation continued (Fig. 3).

Macromolecular composition of akinetes and vegetative cells. The most pronounced changes in cellular macromolecular composition during akinete differentiation were the 16-fold increase in glycogen and the 8-fold increase in cyanophycin content (Table 1). The total dry weight, carbon and chlorophyll $a$ contents of the akinete were approximately double those of vegetative cells; the nitrogen content increased by $17 \%$, while the other components measured remained constant (Table 1). On a dry weight basis, only cyanophycin and glycogen increased; carbon and chlorophyll $a$ remained constant, and other components decreased. The sum of the protein, cyanophycin and nucleic acid contents of the vegetative cells $(6.86 \mathrm{pg})$ accounts for $97 \%$ of the cell dry weight. In contrast, these macromolecules comprise only $49.5 \%$ of the akinete dry weight. The extra carbon content $(3.3 \mathrm{pg})$ of the akinete accounts for a further $22 \%$ of the dry weight; the remaining $28 \%$ is at present unexplained.

Environmental factors which affect akinete differentiation. Akinete differentiation usually commenced when the culture density $\left(A_{650}\right)$ reached $2 \cdot 0$. On reducing the light intensity from the normal $8000 \mathrm{~lx}$ to $5000 \mathrm{~lx}$, akinetes appeared at a lower culture density $\left(A_{650} 0.94\right)$; when the intensity was increased to $10000 \mathrm{~lx}$, exponential growth was prolonged and akinete differentiation was delayed until the culture density was 3.2 (Fig. 4). Akinete differentiation was therefore not induced by limitation of inorganic nutrients at the normal culture density ( $A_{650} 2.0$ at $8000 \mathrm{~lx}$ ), since, if it were, differentiation would have occurred at the same culture density even at higher light intensity. Under normal growth conditions, the akinetes did not germinate in the culture following maturation. When the light intensity was increased from 8000 to $11000 \mathrm{~lx}$ following the completion of akinete differentiation, akinetes germinated in situ within the filaments, further indicating that inorganic nutrients were not limiting in the medium during differentiation. Exogenous sucrose ( $0.2 \%)$, like increased light intensity, prolonged the exponential growth phase of cultures incubated at $8000 \mathrm{~lx}$ (Fig. 4) and akinete 
Table 1. Cellular composition of akinetes and vegetative cells of Nostoc 7524

Numbers in parentheses indicate the content as a percentage of the dry weight.

Component
Chlorophyll $a$
Phycocyanin
Total protein $†$
Cyanophycin
Glycogen
DNA
RNA
Total nitrogen
Total carbon
Total dry weight

Mean cellular content $(\mathrm{pg})$

\begin{tabular}{|c|c|}
\hline Akinete & Vegetative cell* \\
\hline $0 \cdot 31 \quad(2 \cdot 1)$ & $0 \cdot 15 \quad(2 \cdot 1)$ \\
\hline $0.82 \quad(5.5)$ & $0.88(12.4)$ \\
\hline $4.47(30.0)$ & $4 \cdot 76(67 \cdot 0)$ \\
\hline $0 \cdot 81 \quad(5 \cdot 4)$ & $0.10 \quad(1.4)$ \\
\hline $2 \cdot 30(15 \cdot 4)$ & $0 \cdot 14 \quad(2 \cdot 0)$ \\
\hline $0.09(0.63)$ & $0.10 \quad(1.4)$ \\
\hline $2 \cdot 0 \quad(13.4)$ & $1.9 \quad(26 \cdot 8)$ \\
\hline $0.88 \quad(5.9)$ & $0.75(10 \cdot 6)$ \\
\hline $6 \cdot 3 \quad(42 \cdot 2)$ & $3.0 \quad(42 \cdot 3)$ \\
\hline $4 \cdot 9$ & $7 \cdot 1$ \\
\hline
\end{tabular}

* Values refer to exponentially growing vegetative cells.

+ Values for total protein exclude cyanophycin, which is not measured by the Lowry method (Simon, $1977 a)$.

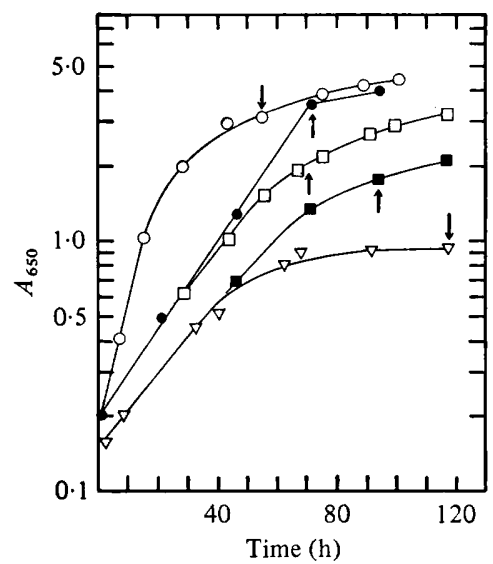

Fig. 4

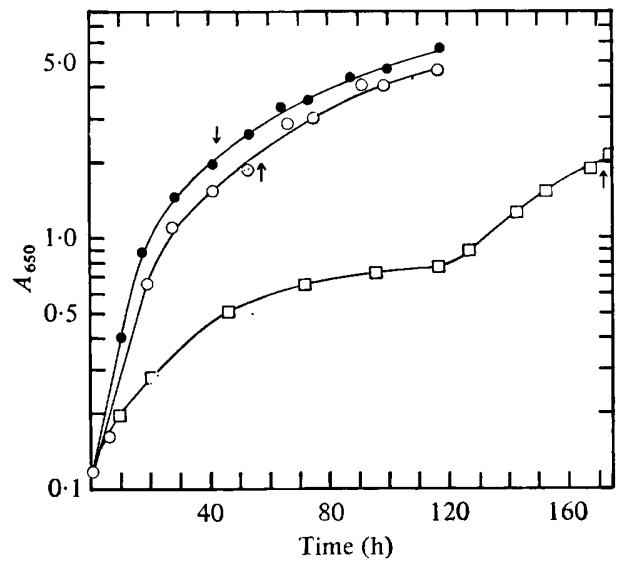

Fig. 5

Fig. 4. Growth and the time of akinete differentiation (indicated by arrows) in $\mathrm{N}_{2}$-grown cultures at light intensities of $10000 \mathrm{~lx}(\bigcirc), 8000 \mathrm{~lx}(\square)$ and $5000 \mathrm{~lx}(\nabla)$, and at $8000 \mathrm{~lx}$ in the presence of $0.2 \%$ sucrose $(O)$ or $0.2 \%$ glucose $(\square)$. Growth and akinete differentiation in acetate $(0.2 \%)$ were similar to glucose (not shown).

Fig. 5. Growth and the time of akinete differentiation (indicated by arrows) in cultures grown at $8000 \mathrm{~lx}$ in the presence of $\mathrm{NH}_{4}{ }^{+}(\bigcirc)$ or glutamine $(O)$ or in the absence of phosphate $(\square) . \mathrm{K}_{2} \mathrm{HPO}_{4}$ $\left(39 \mathrm{mg} \mathrm{l}^{-1}\right)$ was re-added to the last culture at $110 \mathrm{~h}$; the addition of a 10 -fold excess gave similar results (not shown). Cultures grown in $\mathrm{NO}_{3}{ }^{-}$behaved like $\mathrm{NH}_{4}{ }^{+}$-grown cultures (not shown).

differentiation then commenced at a higher culture density $\left(A_{650} 3 \cdot 5\right)$. Neither acetate nor glucose (up to $0.5 \%$ ) affected akinete differentiation (Fig. 4). Unlike sucrose, neither of these compounds served as sole carbon source under photoheterotrophic growth conditions in the presence of $10^{-5} \mathrm{M}$-DCMU.

When cultures growing exponentially ( $20 \mathrm{~h}$ after inoculation) on air $/ \mathrm{CO}_{2}(95: 5, \mathrm{v} / \mathrm{v})$ were changed to air, growth ceased and akinetes were not produced. Cultures which were entering the non-exponential phase of growth at the time $(45 \mathrm{~h})$ of a similar change of gas phase still produced akinetes at the same time as control cultures $\left(\mathrm{air} / \mathrm{CO}_{2}\right)$, while cultures which were changed to $\mathrm{O}_{2} / \mathrm{N}_{2}(21: 79, \mathrm{v} / \mathrm{v})$ at $45 \mathrm{~h}$ did not produce akinetes. Thus, a continued, but limited, supply of carbon seems necessary for akinete differentiation.

On transferring exponentially growing Nostoc 7524 to phosphate-free medium, growth ceased after $80 \mathrm{~h}$ (Fig. 5) and, although cyanophycin accumulated, akinetes were never 
produced. The re-addition of phosphate led to a resumption of growth with akinete differentiation then beginning at the usual culture density at $8000 \mathrm{~lx}$ (Fig. 5), even in the presence of a 10-fold excess of phosphate. When exponentially growing cultures of Nostoc 7524 were transferred to cell-free medium derived from old akinete-containing cultures, growth ceased after $48 \mathrm{~h}$, cyanophycin accumulated in the vegetative cells, but akinetes were not produced. However, on adding phosphate to such cultures, vegetative cell growth resumed and akinetes again differentiated at the normal culture density; thus the cessation of growth in such media was due to phosphate limitation.

Exogenous sources of combined nitrogen $\left(\mathrm{NO}_{3}{ }^{-}, \mathrm{NH}_{4}{ }^{+}\right.$or glutamine) did not affect akinete development, since differentiation occurred in all cases at the normal culture density $\left(A_{650} 2 \cdot 0\right)$ at $8000 \mathrm{~lx}$. The time of akinete appearance, however, changed from approximately $70 \mathrm{~h}$ to $58 \mathrm{~h}$ in the presence of $\mathrm{NO}_{3}{ }^{-}$and $\mathrm{NH}_{4}{ }^{+}$and to $43 \mathrm{~h}$ in the presence of glutamine, as the growth rates of the cultures were increased on combined nitrogen (Fig. 5). The presence of combined nitrogen did not affect any cellular parameter measured except that neither $\mathrm{N}_{2}$ fixation nor heterocyst differentiation occurred in the presence of $\mathrm{NH}_{4}{ }^{+}$.

Nitrogen starvation (replacement of $\mathrm{N}_{2}$ by Ar) in the presence of $\mathrm{CO}_{2}$ stopped growth and cyanophycin production and arrested akinete formation, even in cultures which had commenced cyanophycin accumulation. Akinetes developed normally in cultures grown on $\mathrm{NO}_{3}{ }^{-}$in the same gas phase. Thus, akinete differentiation in Nostoc 7524 required the continued presence of a nitrogen source.

Effect of inhibitors of macromolecular synthesis on akinete formation. On adding chloramphenicol $\left(100 \mu \mathrm{g} \mathrm{ml}^{-1}\right)$ to cultures entering non-exponential growth, growth immediately ceased and no akinetes differentiated although cyanophycin granules appeared, as Simon (1973) noted in Anabaena cylindrica. Rifampicin $\left(5 \mu \mathrm{g} \mathrm{ml}^{-1}\right)$, which inhibited RNA synthesis, also inhibited growth and akinete differentiation. Phenylethanol $(0.075 \%$, $\mathrm{v} / \mathrm{v}$ ) inhibited DNA synthesis as in other bacteria (Altenbern, 1968), and growth ceased within $6 \mathrm{~h}$ of its addition; although cyanophycin continued to be synthesized, mature akinetes were not produced.

Spatial pattern of akinete differentiation in cultures grown on different nitrogen sources. At the onset of differentiation in $\mathrm{N}_{2}$-grown cultures, $42 \%$ of the first-formed akinetes developed exactly at the centre of the interheterocyst interval or within $5 \%$ (mean 1 cell) of the centre (Fig. $6 a$ ); $45 \%$ developed within 2 cells of the centre and $13 \%$ within 3 cells. The positions of newly differentiating heterocysts relative to the centre of existing interheterocyst intervals showed a similar distribution during exponential growth (Fig. $6 b$ ). Similar spatial patterns of akinete (Fig. $6 c$ ) and heterocyst (Fig. $6 d$ ) differentiation occurred in cultures grown in the presence of $\mathrm{NO}_{3}{ }^{-}$; such cultures fixed $\mathrm{N}_{2}$ at normal rates.

In the most common interheterocyst intervals (mean length 18 cells), akinetes developed only at a single site which was equidistant from the heterocysts (Table 2). Consequently, at the onset of differentiation, most interakinete intervals were regular (Fig. 7a) with a mean length of 18 cells, and similar to the interheterocyst intervals at this stage of growth (Fig. 7 b). However, about $15 \%$ of the akinete sites developed close together (mean interval 2 to 10 cells) within the same interheterocyst interval (Fig. $7 a$ ); these multiple sites were observed only in the longer intervals (Table 2). In most of these (mean length $25 \pm 3.8$ cells), akinetes developed at two sites, each $9 \cdot 3 \pm 2 \cdot 2$ cells from the nearest heterocyst and separated by about 6 vegetative cells. In longer interheterocyst intervals $(31.4 \pm 4.2$ cells $)$ three akinete sites developed, with two of them each being $9 \cdot 7 \pm 2 \cdot 4$ cells from the nearest heterocyst and separated by approximately 12 vegetative cells. The third site developed at the centre of this interakinete interval. Thus, akinetes always first developed at sites which were separated from the nearest heterocyst by 9 to 10 vegetative cells; akinete differentiation did not occur in interheterocyst intervals which were less than 18 cells in length (Table 2).

Within $10 \mathrm{~h}$ of the onset of differentiation, the regular akinete spatial pattern observed in the early stages had changed; new akinete sites developed between heterocysts and exist- 
Table 2. Initial spatial pattern of akinetes in interheterocyst intervals of different length

No. of akinete sites in interval Frequency ( $\%$ of total intervals) Mean interheterocyst interval* Mean akinete-heterocyst interval* Mean no. of akinetes per site

$\begin{array}{cccc}0 & 1 & 2 & 3 \\ 23 & 61 & 13 \cdot 5 & 2 \cdot 5 \\ 16 \cdot 7 \pm 5 \cdot 7 & 17 \cdot 8 \pm 4 \cdot 1 & 25 \cdot 0 \pm 3 \cdot 8 & 31 \cdot 4 \pm 4 \cdot 2 \\ - & 8 \cdot 8 \pm 2 \cdot 0 & 9 \cdot 3 \pm 2 \cdot 2 & 9 \cdot 7 \pm 2 \cdot 4 \\ - & 1 \cdot 4 & 1 \cdot 2 & 1 \cdot 4\end{array}$

* \pm Standard deviation.

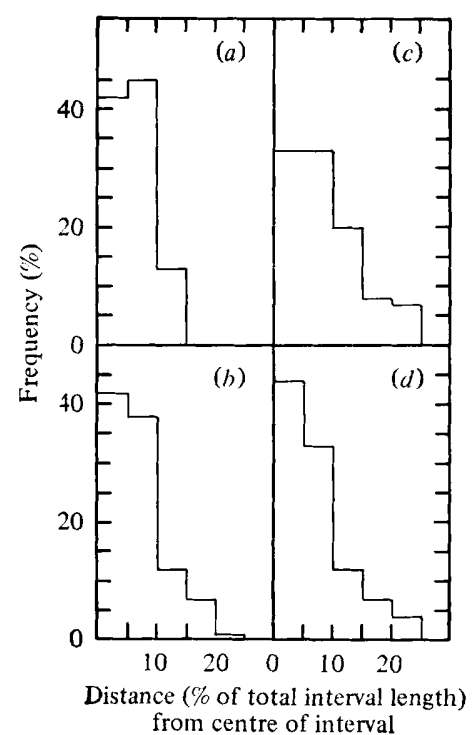

Fig. 6

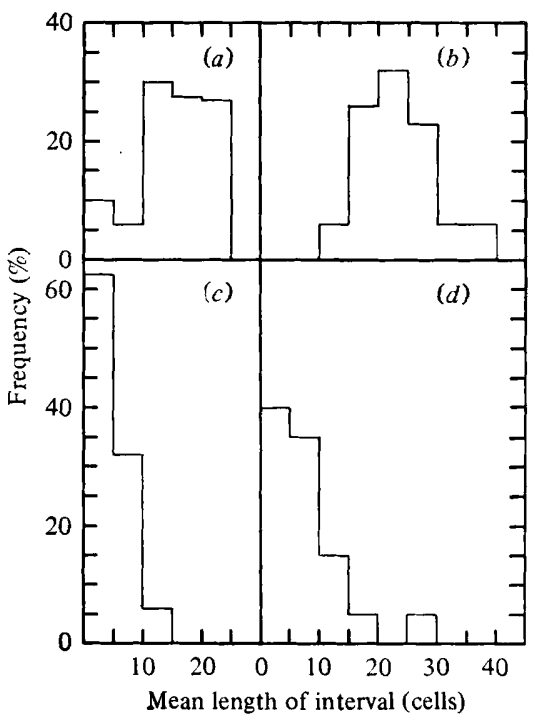

Fig. 7

Fig. 6. The positions, relative to the centre of existing interheterocyst intervals, of akinetes at the onset of differentiation in cultures grown with $\mathrm{N}_{2}$ as sole nitrogen source $(a)$ and in the presence of $\mathrm{NO}_{3}-(c)$, and the positions of newly differentiating heterocysts during exponential growth under $\mathrm{N}_{2}(b)$ and in the presence of $\mathrm{NO}_{3}{ }^{-}(d)$. Light intensity $8000 \mathrm{~lx}$.

Fig. 7. Mean lengths of interakinete intervals at the onset of differentiation in cultures grown under $\mathrm{N}_{2}(a)$; mean interheterocyst intervals in the same culture at the onset of akinete differentiation (b); mean interakinete intervals in the same culture $10 \mathrm{~h}$ later $(c)$; mean interakinete intervals at the onset of differentiation in the presence of $\mathrm{NH}_{4}{ }^{+}(d)$. Light intensity $8000 \mathrm{~lx}$.

ing akinetes, resulting in a decrease of the mean interakinete interval (Fig. 7c). The proportion of interheterocyst intervals containing several akinete sites increased from 16 to $26 \%$, and akinetes also developed in $33 \%$ of the shorter intervals which previously did not contain akinetes. The increase in the number of akinete sites (from 40 to 58 per 1000 cells), together with an increase in the mean number of akinetes per site (from 1.3 to $2 \cdot 0$ ), caused the akinete frequency to increase from 5 to $12 \%$. The final akinete frequency $(60 \%)$ was achieved mostly by further increase in the number of akinetes at each site as new akinetes differentiated successively on either side of the first, forming gradients of maturity with the oldest akinete in the centre of the chain (Fig. $9 b$ ).

In cultures grown on $\mathrm{Ar} / \mathrm{CO}_{2}(95: 5, \mathrm{v} / \mathrm{v})$ plus $\mathrm{NO}_{3}{ }^{-}$, heterocyst (Fig. $8 a$ ) and akinete (Fig. $8 b$ ) spatial patterns were similar to those observed in $\mathrm{N}_{2}$-grown cultures (Fig. 6). Cultures grown on $\mathrm{NH}_{4}{ }^{+}$did not produce heterocysts. Akinetes, however, developed, but in an altered spatial pattern in which the interakinete intervals were irregular (Fig. $7 d$ ) and reduced from a mean of 18.0 to 8.2 cells; the number of akinete sites which appeared at the onset of differentiation was increased from 40 to 123 per 1000 vegetative cells.

Effect of 7-azatryptophan on the spatial pattern of akinete production. As Mitchison \& 


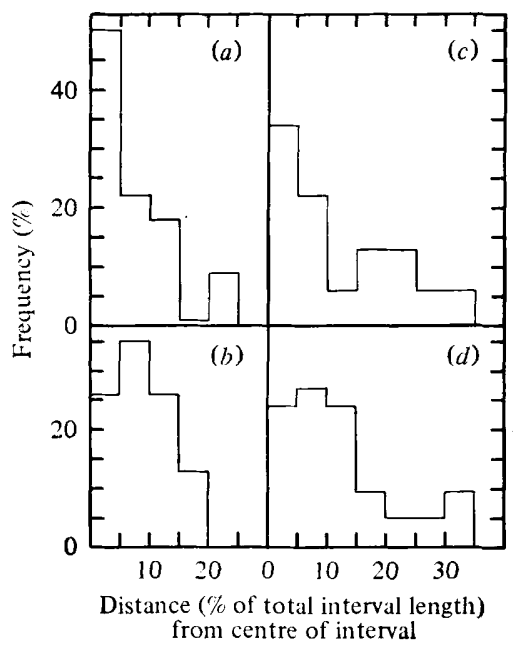

Fig. 8. The positions, relative to the centre of existing interheterocyst intervals, of newly differentiated heterocysts in exponentially growing cultures in the presence of $\mathrm{Ar} / \mathrm{CO}_{2}$ plus $\mathrm{NO}_{3}^{-}(a)$ and 7-azatryptophan plus $\mathrm{NO}_{3}^{-}(c)$, and the positions of akinetes at the onset of differentiation in $\mathrm{Ar} / \mathrm{CO}_{2}$ plus $\mathrm{NO}_{3}^{-}(b)$ and 7-azatryptophan plus $\mathrm{NO}_{3}^{-}(d)$. Light intensity $8000 \mathrm{~lx}$.

Wilcox (1973) observed, 7-azatryptophan $\left(10 \mathrm{mg} \mathrm{1}^{-1}\right)$ altered the pattern of heterocyst spacing during exponential growth, with up to 5 heterocysts occurring in chains. Of the newly differentiating heterocysts, $38 \%$ arose at sites more than $15 \%$ from the centre of existing interheterocyst intervals (Fig. $8 \mathrm{c}$ ), the corresponding value in the absence of 7-azatryptophan being $11 \%$ (Fig. 6d). 7-Azatryptophan also inhibited $\mathrm{N}_{2}$ fixation (data not shown), as in Anabaena cylindrica (Bothe \& Eisbrenner, 1977), and consequently also prevented akinete differentiation when added to cultures growing exponentially on $\mathrm{N}_{\mathbf{2}}$. In the presence of $\mathrm{NO}_{3}{ }^{-}$and 7-azatryptophan, akinetes appeared but in an abnormal pattern which resembled the altered heterocyst pattern; $30 \%$ developed at sites more than $15 \%$ from the centre of the interheterocyst intervals (Fig. $8 d$ ), compared with $15 \%$ in the absence of 7-azatryptophan (Fig. 6c), and the number of akinete sites was increased from 40 to 66 per 1000 vegetative cells at the onset of differentiation.

Structural changes during akinete differentiation. The first visible event in the production of akinetes was the accumulation of refractile bodies in one or several vegetative cells midway between heterocysts (Fig. 9a). These stained positively for arginine by the Sakaguchi test (Fogg, 1951) and corresponded to cyanophycin granules. Subsequently, cyanophycin accumulated in cells progressively closer to the heterocysts, producing chains of granular cells (Fig. 9b), and often cccurred in dividing cells (Fig. 9c). Cyanophycin-containing cells then enlarged, extracellular envelopes were produced and the wall became greatly thickened (see also Wildon \& Mercer, 1963; Miller \& Lang, 1968; Jensen \& Clark, 1969).

The first stage in envelope formation was the appearance of a loose fibrillar material which developed first around the equatorial region of the cells and later at the poles (Fig. $9 f$ ). This process commenced in the central cell of the chain of immature akinetes, and subsequently occurred in the cells on either side. Completion of envelope formation resulted in filament fragmentation, but akinetes continued to be produced in the broken filaments and a gradient of maturity resulted with the more mature akinetes at the ends (Fig. $9 f$ ).

Soon after deposition of the loose fibrillar material, it became separated from the cell wall by an electron-translucent area of variable thickness (Fig. 10b). A third layer, uniformly thick and composed of moderately electron-dense material, then formed between the fibrillar and electron-translucent layers (Fig. 10c). This had a more ordered appearance than the 

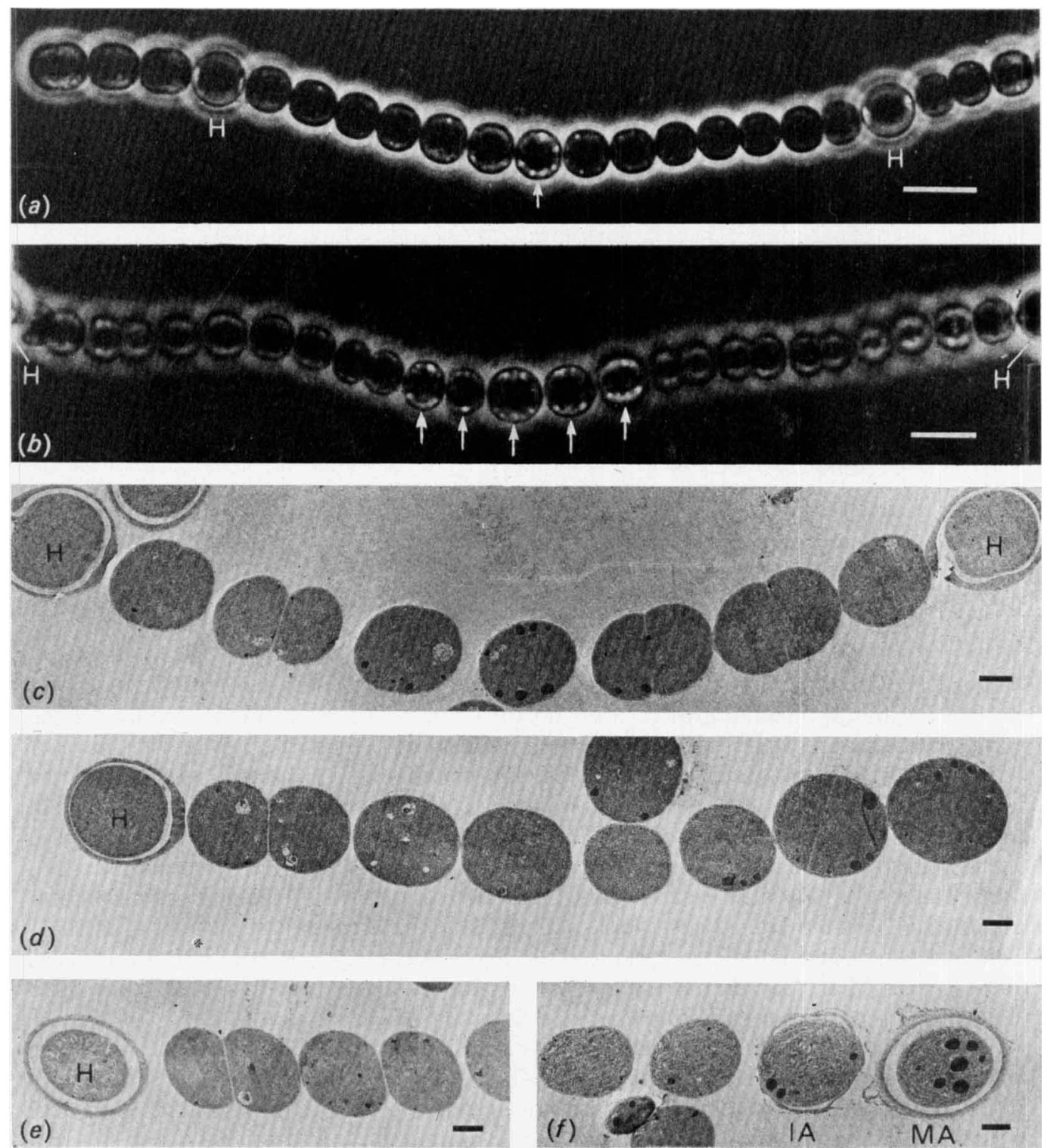

Fig. 9. Bar markers represent $5 \mu \mathrm{m}$ in $(a, b)$ and $1 \mu \mathrm{m}$ in (c to $f)$. H, Heterocyst; IA, immature akinete; MA, mature akinete.

(a) A filament containing two heterocysts and showing accumulation of cyanophycin granules (refractile bodies) in a cell (arrowed) close to the centre of the interheterocyst interval. Phase contrast.

(b) A filament with a longer interheterocyst interval than that in (a), showing enlargement and cyanophycin accumulation in a group of cells (arrowed) in the centre of the interval. Phase contrast.

(c) Electron micrograph of a section through a filament. A similar pattern of accumulation of cyanophycin granules (dark-staining bodies) to that shown in (a) is apparent.

(d) Electron micrograph of a section through a filament similar to that in $(b)$. The cells on the right, containing cyanophycin granules, are approximately midway between heterocysts. The lighter polyphosphate bodies occur in cells closer to the heterocysts.

(e) Electron micrograph of a filament containing a heterocyst which has not been sectioned through the pole. The heterocyst envelope is similar to that of the akinete in $(f)$.

(f) Electron micrograph showing a mature akinete at the end of a broken filament with an adjacent immature akinete. 
fibrillar layer which, at this stage, became thinner, more electron-dense and unevenly distributed (Fig. 10c,d). The electron-translucent area became more pronounced and superficially resembled that of the heterocyst (Fig. $9 c, d, e$ ). However, its appearance was not altered by fixation with either potassium permanganate, glutaraldehyde/dimethyl sulphoxide, paraformaldehyde or acrolein; neither did it show any electron density after a variety of staining techniques. During envelope formation the intermediate layer of the cell wall became less electron-dense and increased in thickness from approximately 10 to $70 \mathrm{~nm}$ (Fig. $10 e$ to $h$ ), causing the total thickness of the wall to increase from approximately 50 to $110 \mathrm{~nm}$.

The polyglucoside, polyhedral and lipid body content of the cells did not change visibly during akinete differentiation. Polyphosphate bodies were rare in mature akinetes, although they were commonly present in vegetative cells during akinete differentiation (Fig. $9 c, d$ ).

Resistance of akinetes to extreme conditions. On storage at $4{ }^{\circ} \mathrm{C}$ in the dark for 15 months, $95 \%$ of the akinetes germinated when transferred to normal growth conditions, while over $90 \%$ of the vegetative cells became inviable within $7 \mathrm{~d}$ at this temperature. Approximately $45 \%$ of the akinetes survived freezing at $-20{ }^{\circ} \mathrm{C}$ where all vegetative cells were killed, and $22 \%$ survived two cycles of freezing and thawing. Akinete germination was also observed at high, but variable, frequencies ( 45 to $80 \%$ ) following desiccation for 6 months. In contrast, akinetes were sensitive to high temperatures. The maximum temperature permitting growth of vegetative cells was $41^{\circ} \mathrm{C}$; akinete viability was reduced to less than $5 \%$ following $10 \mathrm{~min}$ incubation at $45^{\circ} \mathrm{C}$.

\section{DISCUSSION}

Nostoc 7524 produced two differentiated cell types, heterocysts and akinetes. Their development was temporally separated, heterocysts being produced only during exponential growth and akinetes appearing only during the linear (post-exponential) phase of growth. Akinete differentiation was well synchronized only in cultures which were stirred to maintain a homogeneous suspension. In unstirred cultures differentiation was asynchronous and occurred in some filaments at an early stage of growth; such filaments were contained in large aggregates of material and were light-limited. This illustrates both the importance of maintaining homogeneous suspensions in these studies and the difficulties which may be encountered with organisms which normally grow in aggregates.

The transition from exponential to linear growth was caused by limitation of energy rather than of inorganic nutrients, since exponential growth and heterocyst differentiation were prolonged, and akinete differentiation was delayed until a higher culture density was reached, by increasing the light intensity or by the addition of a utilizable carbon source (sucrose). Energy limitation appeared to be the only major factor involved in the induction of akinete differentiation. Unlike Anabaena cylindrica (Wolk, 1965), phosphate deprivation did not induce differentiation in Nostoc 7524; indeed, differentiation occurred even in the presence of excess phosphate when light became limiting. Sodium chloride (Canabaeus, 1929), glutamate (Demeter, 1956) and glucuronate (Wolk, 1965), which stimulated akinete differentiation in other cyanobacteria, had no effect on Nostoc 7524 and, unlike Cylindrospermum licheniforme (Fischer \& Wolk, 1976), akinete-containing cultures of Nostoc 7524 did not appear to produce an extracellular compound which induced akinete differentiation in younger cultures. Although nitrogenase activity declined at the end of exponential growth, nitrogen limitation did not appear to be involved in the induction of differentiation since a continued supply of nitrogen was required and, in contrast to $A$. doliolum (Singh \& Srivastava, 1968), the process was not inhibited by exogenous supplies of combined nitrogen.

Increased light intensity (Fig. 4), and the addition of sources of combined nitrogen (Fig. 5), caused akinete differentiation to occur sooner than in control cultures grown in $\mathrm{N}_{2}$ at 8000 lx. In the absence of data on growth rate, these results would be interpreted as a 

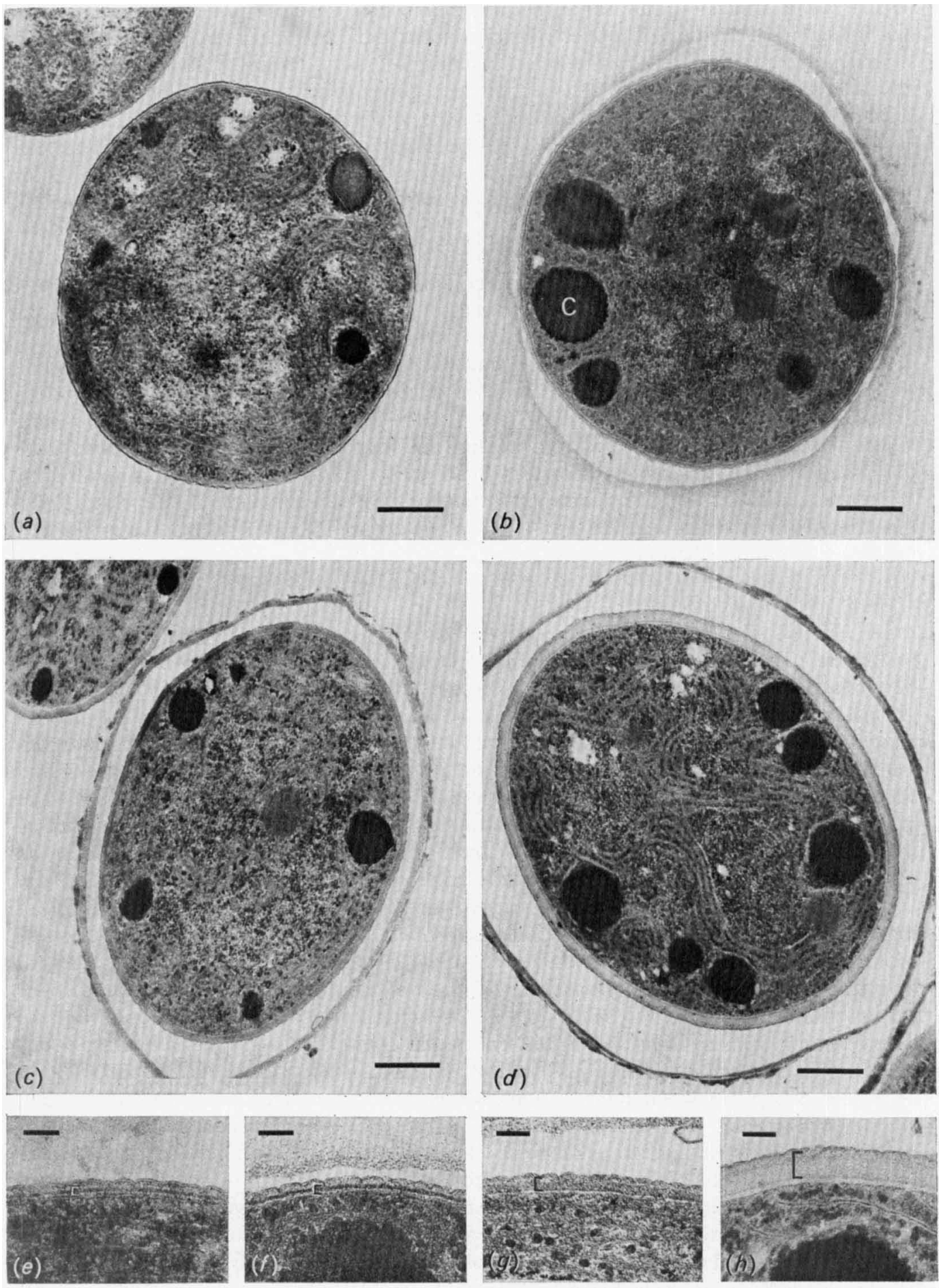
stimulation of akinete formation. However, the only effect of these conditions was to increase the exponential growth rate of the culture; in all cases, akinetes developed in the post-exponential phase of growth when light became limiting. Under optimum growth conditions, akinete differentiation in Nostoc PCC 6720, Anabaena PCC 7108 and Cylindrospermum PCC 7417 was similarly observed only after the end of exponential growth (unpublished results). It is clear, therefore, that the time course of akinete differentiation relative to growth must be examined if the nutritional factors which influence differentiation are to be investigated. Only Fay (1969b) and Simon (1977a) have provided such data; in both cases, as in the present study, akinete differentiation in $A$. cylindrica occurred at the end of the exponential phase of growth, although the importance of light limitation was not examined. Akinete differentiation in five species of planktonic cyanobacteria in nature occurred only when light was limiting (Rother \& Fay, 1977). The same environmental trigger may therefore operate in all cases.

The most striking physiological features of akinete differentiation were accumulation of glycogen and cyanophycin, and increase in carbon content and dry weight at a rate which exceeded that of protein synthesis. Differentiation in $A$. cylindrica also involved increase in dry weight of the culture (Fay, $1969 a$; Simon, $1977 a$ ) without protein'synthesis(Simon, 1977a). In contrast to A.cylindrica (Fay, 1969a) the chlorophyll a content of the Nostoc 7524 akinete was higher than that of vegetative cells, while the phycocyanin content was unchanged. The ratio of RNA:DNA (19:1) in the vegetative cells was slightly greater than that (13:1) in $A$. cylindrica (Simon, 1977b), but the akinetes did not possess the increased RNA content characteristic of those of the latter organism (Simon, 1977b). In containing the same amount of DNA as vegetative cells the akinetes resembled those of $A$. cylindrica (Simon, 1977b) and differed from Cylindrospermum (Ueda \& Sawada, 1972). Their mean content of 9.4× $10^{-14} \mathrm{~g}$ corresponded to 10 genome equivalents, since the genome molecular weight was $5.6 \times 10^{9}$ (Herdman et al., 1979). Since the macromolecular composition of cyanobacteria varies with growth rate (Leach et al., 1971; Mann \& Carr, 1974), the values presented here are absolute only for the growth conditions employed.

As in other cyanobacteria (Fogg et al., 1973; Yamamoto, 1975), akinetes of Nostoc 7524 serve a perennating role. Factors which contribute to their success include their high cyanophycin content which makes them independent of exogenous $\mathrm{N}_{2}$ during germination (unpublished results), their release by filament breakage following envelope formation, and their resistance to both low temperature and desiccation. Like Azotobacter cysts (Sadoff et al., 1975) akinetes of Nostoc 7524 are sensitive to high temperatures and in this respect differ from bacterial endospores.

When heterocysts were absent (in cultures grown on $\mathrm{NH}_{4}^{+}$) the akinete spatial pattern was irregular even at the onset of differentiation, with akinetes differentiating simulttaneously in random positions along the filament. Similar random patterns were observed in Nostoc 7524 mutants unable to produce heterocysts (unpublished results). Thus, in

Fig. 10. Bar markers represent $500 \mathrm{~nm}$ in ( $a$ to $d)$ and $100 \mathrm{~nm}$ in (e to $h$ ).

(a) Vegetative cell.

(b) An early stage in the development of an akinete showing accumulation of cyanophycin (C). Loose fibrillar material has been deposited outside the cell wall and has become separated from it by an electron-translucent area of variable thickness.

(c) A maturing akinete, showing a layer of moderate electron density and relatively uniform thickness between the outer fibrillar layer and the electron-translucent layer. The latter is of more uniform thickness than that in $(b)$, and the cell wall is slightly thicker.

(d) A mature akinete, showing two outer envelope layers, the electron-translucent envelope layer and a greatly thickened cell wall.

$(e$ to $h$ ) Higher magnifications of ( $a$ to $d$ ) respectively, showing that the increase in thickness of the cell wall during akinete maturation is due to the thickening of the intermediate wall layer (indicated) which also becomes progressively less electron-dense. 
contrast to $A$. cylindrica (Wolk, 1966), heterocysts were not necessary for akinete differentiation in Nostoc 7524; their presence, however, resulted in a regular and predictable initial spatial pattern of akinete development, suggesting that the heterocysts themselves regulate the pattern. The similar alterations in both heterocyst and akinete spatial patterns caused by 7-azatryptophan, which also altered the heterocyst spatial pattern in $A$. catenula (Mitchison \& Wilcox, 1973) and A. cylindrica (Bothe \& Eisbrenner, 1977), suggests that the control of the two patterns is related. Cultures incubated in the absence of atmospheric $\mathrm{N}_{2}$ (gas phase $\mathrm{Ar} / \mathrm{CO}_{2}$ ) with $\mathrm{NO}_{3}^{-}$as sole nitrogen source produced heterocysts in the normal spatial pattern throughout exponential growth; as in A. cylindrica (Bradley \& Carr, 1976) the control of heterocyst spacing is therefore independent of $\mathrm{N}_{2}$ fixation by the heterocysts. During the post-exponential phase of growth under the same conditions, akinetes developed in normal positions relative to heterocysts. The control of the akinete spatial pattern is therefore also independent of $\mathrm{N}_{2}$ fixation.

This work was supported by the S.R.C. We thank Dr Peter Rowell for advice on certain estimations and John Reaston for performing the nucleic acid measurements.

\section{REFERENCES}

Altenbern, R. A. (1968). Chromosome mapping in Staphylococcus aureus. Journal of Bacteriology $\mathbf{9 5}$, 1642-1646.

BENNETT, A. \& Bogorad, L. (1973). Complementary chromatic adaptation in a filamentous bluegreen alga. Journal of Cell Biology 58, 419-435.

Bornet, E. \& Flahaut, C. (1888). Révision des Nostocacées Hétérocystées. Annales des sciences naturelles (Botanique) 7, 177-262.

Bothe, H. \& Eisbrenner, G. (1977). Effect of 7-azatryptophan on nitrogen fixation and heterocyst formation in the blue-green alga Anabaena cylindrica. Biochimie und Physiologie der Pflanzen $171,323-332$.

BradLeY, S. \& CARR, N. G. (1976). Heterocyst and nitrogenase development in Anabaena cylindrica. Journal of General Microbiology 96, 175-184.

Canabaeus, L. (1929). Über die Heterocysten und Gasvakuolen der Blaualgen und ihre Beziehung zueinander. Pflanzenforschung 13, 1-48.

Coulter, D. B. \& Aronson, J. M. (1977). Glycogen structure and utilisation in Allomyces macrogynus. Experimental Mycology 1, 183-193.

DEMETER, O. (1956). Über Modifikationen bei Cyanophyceen. Archiv für Mikrobiologie 24, 105-133.

FAY, P. (1969a). Cell differentiation and pigment composition in Anabaena cylindrica. Archiv für Mikrobiologie 67, 62-70.

FAY, P. (1969b). Metabolic activities of isolated spores of Anabaena cylindrica. Journal of Experimental Botany 20, 100-109.

FischeR, R. W. \& Wolk, C. P. (1976). Substance stimulating the differentiation of spores of the blue-green alga Cylindrospermum licheniforme. Nature, London 259, 394-395.

FoGG, G. E. (1951). Growth and heterocyst production in Anabaena cylindrica Lemm. III. The cytology of heterocysts. Annals of Botany 15, 23-35.

Fogg, G. E., Stewart, W. D. P., Fay, P. \& WalsBy, A. E. (1973). The Blue-Green Algae. London: Academic Press.
FrITsCH, F. E. (1904). Studies on Cyanophyceae. III. Some points in the reproduction of Anabaena. New Phytologist 3, 216-228.

FrITSCH, F. E. (1951). The heterocyst: a botanical enigma. Proceedings of the Linnean Society of London 162, 194-211.

Herdman, M., JanVier, M., RIPPKa, R. \& Stanier, R. Y. (1979). Genome size of cyanobacteria. Journal of General Microbiology 111, 73-85.

Jensen, T. E. \& Clark, R. C. (1969). Cell wall and coat of the developing akinete of a Cylindrospermum species. Journal of Bacteriology 97, 1494-1495.

Leach, C. K., Old, J. M. \& CarR, N. G. (1971). Aspects of macromolecular synthesis in the bluegreen alga Anabaena variabilis. Journal of General Microbiology 68, xiv.

LloYd, J. B. \& WhelaN, W. J. (1969). An improved method for enzymatic determination of glucose in the presence of maltose. Analytical Biochemistry 30, 467-469.

MANN, N. \& CARR, N. G. (1974). Control of macromolecular composition and cell division in the blue-green alga Anacystis nidulans. Journal of General Microbiology 83, 399-405.

MARKER, A. F. H. (1972). The use of acetone and methanol in the estimation of chlorophyll in the presence of phaeophytin. Freshwater Biology 2, 361-385.

Marshall, J. J. \& Whelan, W. J. (1970). Incomplete conversion of glycogen and starch by crystalline amyloglucosidase and its importance in the determination of amylaceous polymers. FEBS Letters 9, 85-88.

Miller, M. M. \& LaNG, N. J. (1968). The fine structure of akinete formation and germination in Cylindrospermum. Archiv für Mikrobiologie 60, 303-313.

Mitchison, G. J. \& Wilcox, M. (1973). Alteration in heterocyst pattern in Anabaena produced by 7-azatryptophan. Nature New Biology 246, 229-233.

Nichols, J. M. \& CARR, N. G. (1978). Akinetes of 
cyanobacteria. In Spores VII, pp. 335-343. Edited by G. Chambliss \& J. C. Vary. Washington: American Society for Microbiology.

Rippka, R., Deruelles, J., Waterbury, J. B., Herdman, M. \& Stanier, R. Y. (1979). Generic assignments, strain histories and properties of pure cultures of cyanobacteria. Journal of General Microbiology 111, 1-61.

Rother, J. A. \& FAY, P. (1977). Sporulation and the development of planktonic blue-green algae in two Salopian meres. Proceedings of the Royal Society B 196, 317-332.

SAdoff, H. L., Page, W. J. \& Reusch, R. N. (1975). The cyst of Azotobacter vinelandii: comparative view of morphogenesis. In Spores VI, pp. 52-60. Edited by P. Gerhardt, R. N. Costilow \& H. L. Sadoff. Washington: American Society for Microbiology.

SimON, R. D. (1973). The effect of chloramphenicol on the production of cyanophycin granule polypeptide in the blue-green alga Anabaena cylindrica. Archiv für Mikrobiologie 92, 115-122.

Simon, R. D. (1977a). Sporulation in the filamentous cyanobacterium Anabaena cylindrica. The course of spore formation. Archives of Microbiology 111, 283-288.

Simon, R. D. (1977b). Macromolecular composition of spores from the cyanobacterium Anabaena cylindrica. Journal of Bacteriology 129, 1154-1155.
Singh, H. N. \& Srivastava, B. S. (1968). Studies on morphogenesis in a blue-green alga. I. Effect of organic nitrogen sources on developmental morphology of Anabaena doliolum. Canadian Journal of Microbiology 14, 1341-1346.

Stewart, W. D. P., Fitzgerald, G. P. \& Burris, R. H. (1967). In situ studies on $\mathrm{N}_{2}$ fixation using the acetylene reduction technique. Proceedings of the National Academy of Sciences of the United States of America 58, 2071-2078.

Tyagi, V. V. S. (1974). Some observations on the pattern of sporulation in a blue-green alga, Anabaena doliolum. Annals of Botany 38, 11071111.

UEDA, K. \& SAWADA, M. (1972). DNA-content of akinete cells in Cylindrospermum. Cytologia 37, 519-523.

Wildon, D. C. \& MERCER, F. V. (1963). The ultrastructure of the heterocyst and akinete of the blue-green algae. Archiv für Mikrobiologie 47, 19-31.

Wolk, C. P. (1965). Control of sporulation in a blue-green alga. Developmental Biology 12, 15-35.

Wolk, C. P. (1966). Evidence of a role of heterocysts in the sporulation of a blue-green alga. American Journal of Botany 53, 260-262.

YамAмото, Y. (1975). Effect of desiccation on the germination of akinetes of Anabaena cylindrica. Plant and Cell Physiology 16, 749-752. 